\title{
Cardiac tissue regeneration: From protein engineering, gene therapy to human embryonic stem cells
}

\author{
Ronald $\mathrm{Li}^{1}$ \\ ${ }^{I}$ University of California, USA
}

Since heart cells normally lack the ability to regenerate, their malfunction or significant loss due to aging or diseases can lead to lethal consequences (e.g. heart failure and various forms of arrhythmias); myocardial repair is hampered by a severe shortage of donor cells and organs. Self-renewable, pluripotent human embryonic stem cells (hESCs) can provide an unlimited cell source for transplantation. Using a range of cell- and gene-based approaches for driven maturation and bioengineering, we have demonstrated in both small and large animal models that biological alternatives are superior to such conventional treatments as pharmacological and devicebased therapies. In this presentation, common hurdles in using hESCs for cardiac regeneration, their potential solutions and our latest progresses will be discussed.

Cell Research (2008) 18:s103. doi: 10.1038/cr.2008.193; published online 4 August 2008

Correspondence: Ronald Li

E-mail: ronaldli@ucdavis.edu

Dr Ronald Li is currently Associate Professor at the University of California, Davis with appointments in Biomedical Engineering, Biophysics and Cell Biology. He is also Associate Investigator of the Institute of Pediatric Regenerative Medicine at the Shriners Hospital for Children, and Adjunct Associate Professor of Cardiology at the University of Hong Kong. At UC Davis, he runs the hESC Consortium of the Stem Cell Program. Before he moved to CA, he was Assistant Professor at the Johns Hopkins University (2002-5). Dr Li was the two-time recipient of the Top Junior Faculty Research Award from JHU Dept of Medicine (2002 $\&$ 2004), and has also received such honors as the Young Investigator Award from the Heart Rhythm Society (2002), Career Development Award from the Cardiac Arrhythmias Research \& Education Foundation (2001), Top Prize for Young Investigator Basic Research from JHU School of Medicine (2001), etc. His group focuses on bioelectricity and construction of an unlimited library of "custom-tailored" human heart cells. Their work on cardiac differentiation has been recognized by the American Heart Association as The Best Basic Paper of 2005, A Ground-Breaking Study of 2006, and Latebreaking studies of 2003, 2004 and 2007. 